\title{
GAYA HIDUP DAN KEBIASAAN MAKAN MAHASISWA
}

\author{
Anita Saufika $^{\left.{ }^{*}\right)}$, Retnaningsih ${ }^{1}$, Alfiasari $^{1}$ \\ ${ }^{1}$ Departemen IImu Keluarga dan Konsumen, Fakultas Ekologi Manusia, Institut Pertanian Bogor, \\ Bogor 16680, Indonesia \\ *) E-mail: anitasaufika@gmail.com
}

\begin{abstract}
Abstrak
Penelitian ini bertujuan untuk menganalisis pengaruh faktor internal (karakteristik mahasiswa) dan faktor eksternal (karakteristik keluarga, kelompok acuan, dan pola asuh makan) terhadap gaya hidup mahasiswa dan menganalisis pengaruh faktor internal, faktor eksternal, gaya hidup terhadap kebiasaan makan mahasiswa. Mahasiswa yang terlibat dalam penelitian ini berjumlah 120 mahasiswa yang dipilih dengan teknik cluster random sampling. Data dianalisis menggunakan analisis deskriptif, cluster, dan regresi logistik. Hasil penelitian menunjukkan bahwa sebagian besar mahasiswa memiliki gaya hidup berorientasi hiburan dan kesehatan. Gaya hidup dipengaruhi oleh usia mahasiswa, jumlah anggota keluarga, dan kelompok acuan televisi. Mahasiswa laki-laki lebih berpeluang untuk makan tiga kali dalam sehari secara rutin selain dipengaruhi juga oleh bertambahnya usia ayah dan skor kelompok acuan keluarga dan teman. Bertambahnya skor kelompok acuan teman mempengaruhi kebiasaan sarapan sementara bertambahnya skor kelompok acuan keluarga mempengaruhi kebiasaan makan camilan dan makan malam. Jenis kelamin mahasiswa laki-laki dan ibu yang tidak bekerja lebih mempengaruhi kebiasaan makan malam mahasiswa. Selain itu, jenis kelamin mahasiswa perempuan lebih mempengaruhi kebiasaan makan camilan mahasiswa.
\end{abstract}

Kata kunci: kebiasaan makan camilan, kebiasaan makan malam, kebiasaan sarapan, kelompok acuan

\section{Lifestyle and Food Habits of College Students}

\begin{abstract}
This study aimed to analyze the influence of internal (student's characteristics) and external factors (family's characteristics, reference group, foods caring) on the college student's lifestyle and to analyze the influence of internal factors, external factors, and lifestyle on food habits. This study involved 120 college students that selected by cluster random sampling. The data analysis used descriptive, cluster, and logistic regression. The result showed that the most students had an entertainment and health-oriented lifestyle. The lifestyle was influenced by student's age, family size, and television reference group. Male students had more opportunity to eat three times a day routinely beside was influenced by increasing of father's age and family and friends scores as reference groups. Increasing scores of friends as reference group influenced breakfast habits, meanwhile increasing scores of family as reference group influenced snack and dinner habits. Male students and housewife mother more influenced increasing of dinner habits. Moreover, female students more influenced increasing of snack habits.
\end{abstract}

Keywords: breakfast habits, dinner habits, reference group, snack habits

\section{PENDAHULUAN}

Salah satu kelompok usia dalam masa perkembangan adalah periode remaja dan dewasa muda. Pencarian identitas yang menjadi fokus pada periode remaja merupakan proses penting dan sehat yang didasarkan pada periode sebelumnya dan menjadi dasar untuk menghadapi kehidupan orang dewasa. Sementara dewasa muda merupakan periode periode dimana seseorang berada di puncak kesehatan, kekuatan, energi dan daya tahan (Papalia, Old, \& Feldman, 2008). Idealnya, pada periode ini telah terbentuk kebiasaan makan yang ideal dan berat badan ideal. Oleh karenanya kebiasaan makan pada periode remaja dan dewasa muda ini penting untuk diperhatikan karena akan mempengaruhi keoptimalan fungsi sistem organ selama proses penuaan. Gaya hidup serta perilaku yang tidak mendukung konsumsi makanan yang sehat dan bergizi menyebabkan individu kurang mengontrol makanan yang dikonsumsinya. Gaya hidup mempengaruhi kebiasaan makan seseorang atau sekelompok orang dan berdampak tertentu (positif atau negatif) khususnya berkaitan dengan gizi (Suhardjo, 1989).

Mahasiswa merupakan sekelompok individu yang termasuk dalam periode remaja dan dewasa muda. Menurut Suhardjo (1989), 
pada umumnya remaja mempunyai kebiasaan makan yang kurang baik. Beberapa remaja khususnya remaja putri sering mengonsumsi makanan dalam jumlah yang tidak seimbang dibandingkan dengan kebutuhannya karena takut mengalami kegemukan. Hurlock (1980) juga menunjukan bahwa remaja suka sekali jajan makanan ringan, terutama kue-kue yang manis. Sementara itu, golongan sayur-sayuran dan buah-buahan yang mengandung banyak vitamin dan mineral tidak populer di kalangan remaja. Remaja memiliki tingkat konsumsi yang rendah terhadap sayur dan buah-buahan (Sop et al., 2010). Remaja seharusnya memiliki kebiasaan makan yang baik agar status gizinya juga baik (Suhardjo, 1989). Selain itu, kebiasaan makan yang terbentuk saat di akhir periode remaja juga akan mempengaruhi kebiasaan makan seseorang saat dewasa, karena kebiasaan makan terbentuk sejak dini dan akan terbawa sampai waktu yang akan datang.

Hasil penelitian Jelinic, Nola, dan Matanic (2008) menyebutkan bahwa tinggal sendiri atau indekos membuat mahasiswa lebih tidak terbiasa untuk melakukan kebiasaan sarapan. Sarapan merupakan kebiasaan yang paling sering dilewatkan mahasiswa, dibandingkan dengan kebiasaan makan siang dan makan malam (Phujiyanti, 2004). Penelitian Mustopa (2003) juga menemukan bahwa overweight lebih banyak terjadi pada mahasiswa berjenis kelamin laki-laki, sedangkan tubuh yang kurus lebih banyak dimiliki oleh mahasiswa berjenis kelamin perempuan.

Perilaku konsumsi individu dipengaruhi oleh berbagai faktor, salah satunya adalah gaya hidup. Penelitian yang dilakukan oleh Phujiyanti (2004) menemukan bahwa gaya hidup thinker, experiencer, dan believer berhubungan dengan kebiasaan sarapan mahasiswa. Hasil penelitian Jelinic, Nola, dan Matanic (2008) juga menyebutkan bahwa tempat mengonsumsi makanan, frekuensi konsumsi daging, dan aktivitas fisik mempengaruhi gaya hidup dan kebiasaan makan. Sementara itu, gaya hidup juga dapat mempengaruhi status zat gizi, pola konsumsi, dan tingkat konsumsi zat gizi remaja (Sundari, 2003). Temuan-temuan tersebut menegaskan bahwa gaya hidup mempengaruhi perilaku konsumsi seseorang.

Perubahan gaya hidup juga dapat membawa perubahan pada selera, kebiasaan, dan perilaku pembelian. Engel, Blackwell, dan Miniard (1994) menyebutkan bahwa gaya hidup merupakan konsep yang kontemporer, lebih komprehensif, dan lebih berguna daripada kepribadian. Seperti yang dikemukakan oleh Kotler dan Amstrong (2008), gaya hidup seseorang menunjukkan pola kehidupan orang yang bersangkutan di dunia ini sebagaimana tercermin dalam kegiatan, minat, dan pendapatnya. Lebih lanjut Kotler dan Amstrong (2008) juga mengatakan bahwa gaya hidup mencerminkan keseluruhan orang tersebut dalam interaksinya dengan lingkungannya. Interaksi seseorang dengan lingkungannya tak lepas dari pengaruh orang-orang dan keadaan di sekitarnya.

Gaya hidup setiap individu akan dapat berbeda-beda walaupun berasal dari lingkungan keluarga dan budaya yang sama. Menurut Engel, Blackwell, dan Miniard (1994) dan Kotler (1985), individu yang berasal dari subbudaya, kelas sosial, dan pekerjaan yang sama dapat memiliki gaya hidup yang berbeda. Hal ini menunjukkan bahwa gaya hidup dipengaruhi oleh berbagai faktor, baik faktor internal maupun faktor eksternal. Sebuah penelitian di Thailand menunjukkan bahwa gaya hidup konsumen dipengaruhi oleh jenis kelamin, status pernikahan, pendapatan, dan tempat domisili (Suwanvijit \& Promsa-ad, 2009). Gaya hidup individu dapat berubah dan menurut Schiffman dan Kanuk (2004), berubahnya gaya hidup memainkan peran utama dalam menentukan manfaat produk yang penting bagi konsumen. Pada periode dewasa, individu akan menetapkan gaya hidup yang dijalaninya (Turner \& Helms, 1986).

Pentingnya kualitas kesehatan mahasiswa yang ditentukan oleh kebiasaan makannya serta eratnya hubungan antara gaya hidup dan kebiasaan makan maka pengaruh gaya hidup terhadap kebiasaan makan mahasiswa perlu dikaji lebih lanjut. Oleh karena itu, penelitian ini bertujuan untuk menganalisis pengaruh faktor internal dan eksternal mahasiswa terhadap gaya hidup. Selain itu, penelitian ini juga bertujuan untuk menganalisis pengaruh faktor internal, faktor eksternal, dan gaya hidup terhadap kebiasaan makan mahasiswa baik kebiasaan sarapan, makan siang, camilan, dan makan malam.

\section{METODE}

Penelitian ini menggunakan metode survey dan dilakukan di kampus Institut Pertanian Bogor (IPB). Pengambilan data dilakukan pada bulan September sampai dengan bulan Oktober tahun 2011. Populasi dalam penelitian ini adalah mahasiswa IPB tahun ajaran 2011/2012 yang terdiri atas mahasiswa semester tiga, lima, dan tujuh. Pemilihan 
contoh dilakukan dengan menggunakan teknik cluster random sampling dengan jumlah contoh sebanyak 120 mahasiswa.

Data primer yang dikumpulkan meliputi faktor internal, faktor eksternal, gaya hidup, dan kebiasaan makan. Data primer dikumpulkan melalui pengisian kuesioner penelitian (selfreport) dengan didampingi oleh peneliti pada saat pengisiannya. Faktor internal meliputi usia, jenis kelamin, urutan kelahiran, lama kuliah, suku bangsa, agama, uang saku, dan sumber uang saku mahasiswa. Sementara itu, faktor eksternal terdiri atas karakteristik keluarga dan kelompok acuan. Karakteristik keluarga meliputi usia orang tua, pendidikan orang tua, pekerjaan orang tua, pendapatan keluarga, dan besar keluarga. Sementara itu, kelompok acuan terdiri atas kelompok acuan teman, keluarga, dan televisi.

Gaya hidup diukur menggunakan konsep psikografik, berhubungan dengan sifat atau ciri pribadi (psyco) dan profil (graphics). Pengukuran ini mengacu pada pengukuran aktivitas, minat, dan opini (Activities, Interest, dan Opinion) yang biasa disebut dengan $A / O$ inventories (Engel, Blackwell, dan Miniard, 1994). Instrumen yang digunakan merupakan hasil pengembangan peneliti dari Mowen dan Minor (1998) dengan mengembangkan 44 pernyataan yang digunakan untuk mengukur gaya hidup, terdiri atas 15 pernyataan untuk aktivitas, 14 pernyataan untuk minat, dan 15 pernyataan untuk opini. Pilihan jawaban pernyataan menggunakan skala Likert, yaitu sangat tidak setuju (STS), tidak setuju (TS), cukup setuju (CS), setuju (S), dan sangat setuju (SS). Skor yang diberikan untuk masingmasing pilihan jawaban adalah satu untuk jawaban sangat tidak setuju, dua untuk jawaban tidak setuju, tiga untuk jawaban cukup setuju, empat untuk jawaban setuju, dan lima untuk jawaban sangat setuju. Instrumen yang digunakan telah reliabel dengan nilai Cronbach's alpha sebesar 0,623.

Data yang diperoleh diolah dan dianalisis menggunakan analisis deskriptif, analisis kluster, dan uji regresi logistik. Analisis deskriptif digunakan untuk menghitung nilai minimum, maksimum, rata-rata, standar deviasi, dan pengkategorian variabel. Analisis kluster digunakan untuk mengkategorikan jenis gaya hidup. Berdasarkan hasil uji cluster, gaya hidup ini terbagi menjadi dua kategori (gaya hidup berorientasi pendidikan serta gaya hidup berorientasi hiburan dan kesehatan). Sementara itu, analisis regresi logistik digunakan untuk menganalisis pengaruh faktor internal dan eksternal terhadap gaya hidup (1= gaya hidup berorientasi pendidikan, $0=$ gaya hidup tidak berorientasi pendidikan). Berdasarkan hasil analisis klaster, gaya hidup tidak berorientasi pendidikan pada penelitian ini didefinisikan sebagai gaya hidup berorientasi hiburan dan kesehatan.

Analisis regresi logistik juga digunakan untuk menganalisis pengaruh faktor internal, faktor eksternal, dan gaya hidup terhadap kebiasaan makan. Model regresi untuk menjawab tujuan tersebut memiliki variabel independen $\left(x_{i}\right)$ yang tetap dengan variabel dependent $\left(y_{i}\right)$ yang tidak sama. Variabel dependen yang pertama $\left(\mathrm{y}_{1}\right)$ adalah frekuensi makan yang dilihat dari kebiasaan makan tiga kali sehari ( $1=$ makan tiga kali sehari, $0=$ tidak makan tiga kali sehari). Variabel dependen kedua $\left(\mathrm{y}_{2}\right)$ adalah kebiasaan sarapan ( $1=$ rutin sarapan/ hampir setiap hari sarapan, $0=$ tidak rutin sarapan). Variabel ketiga $\left(\mathrm{y}_{3}\right)$ adalah kebiasaan makan siang (1= rutin makan siang, $0=$ tidak rutin makan siang). Variabel keempat $\left(\mathrm{y}_{4}\right)$ adalah kebiasaan makan malam ( $1=$ rutin makan malam, $0=$ tidak rutin makan malam). Variabel dependen terakhir $\left(\mathrm{y}_{5}\right)$ adalah kebiasaan makan camilan ( $1=$ rutin makan camilan, $0=$ tidak rutin makan camilan).

\section{HASIL}

\section{Faktor Internal Mahasiswa}

Usia mahasiswa dalam penelitian ini berkisar antara 18-22 tahun. Rata-rata usia mahasiswa sebesar 19,8 tahun dan standar deviasi sebesar 1,0 tahun. Berdasarkan kategori usia Papalia, Old, \& Feldman (2008), usia mahasiswa ini termasuk ke dalam periode remaja dan dewasa muda. Pada penelitian ini, mahasiswa yang berjenis kelamin perempuan $(58,3 \%)$ jumlahnya lebih tinggi daripada mahasiswa yang berjenis kelamin laki-laki $(41,7 \%)$. Hal ini sesuai dengan data jumlah mahasiswa IPB tahun 2011 secara keseluruhan yang menyatakan bahwa proporsi mahasiswa perempuan $(60,2 \%)$ lebih tinggi dibandingkan mahasiswa laki-laki (39,8\%). Proporsi terbesar mahasiswa ada pada urutan anak sulung, yaitu sebesar 45,8 persen, sedangkan proporsi terkecil berada pada urutan anak bungsu, yaitu sebesar 18,3 persen. Dilihat dari lama kuliah (bulan), lama kuliah mahasiswa berkisar antara 14-27 bulan. Rata-rata lama kuliah mahasiswa 26,5 bulan dan standar deviasi sebesar 9,8 bulan.

Proporsi terbesar mahasiswa dalam penelitian ini berasal dari daerah Jakarta, Bogor, Depok, Tangerang, dan Bekasi 
(Jabodetabek). Mahasiswa dalam penelitian ini tidak hanya berasal dari Pulau Jawa, tetapi juga berasal dari daerah lain yang ada di luar Pulau Jawa. Mahasiswa juga berasal dari berbagai macam suku yang ada di Indonesia. Jumlah mahasiswa terbanyak dalam penelitian ini berasal dari suku Jawa. dan Sunda. Sekitar empat dari sepuluh mahasiswa berasal dari suku Jawa dan tiga dari sepuluh mahasiswa berasal dari suku Sunda. Sisanya berasal dari suku bangsa lainnya, yaitu mahasiswa yang berasal dari suku campuran (Jawa-Sunda, Jawa-Betawi, Melayu-Sunda, dan lain-lain).

Rata-rata uang saku mahasiswa setiap bulannya adalah Rp811.316,67 dengan standar deviasi Rp293.283,29 dan berada pada rentang Rp250.000,00 sampai Rp1.750.000,00. Proporsi terbesar mahasiswa uang saku mahasiswa berkisar antara Rp500.001,00 sampai dengan Rp1.000.000,00 per bulan.

\section{Faktor Eksternal Mahasiswa}

Usia orang tua mahasiswa secara keseluruhan termasuk dalam kategori dewasa. Berdasarkan hasil penelitian, hampir seluruh usia ayah maupun ibu mahasiswa termasuk pada kategori dewasa madya. Usia ayah mahasiswa berada pada rentang 44-59 tahun dengan rata-rata 50,1 tahun dan standar deviasi 4,9 tahun. Usia ibu berada pada rentang 39-53 tahun dengan rata-rata 46,5 tahun dan standar deviasi 4,1 tahun. Hal ini menunjukkan bahwa rata-rata usia ibu mahasiswa lebih muda daripada usia ayah mahasiswa.

Pendidikan tertinggi yang ditempuh oleh orang tua mahasiswa adalah perguruan tinggi (S1/S2/S3) dan tidak ada satu orang pun orang tua mahasiswa yang tidak menamatkan pendidikannya dari Sekolah Dasar (SD). Proporsi terbesar pendidikan ayah mahasiswa $(42,9 \%)$ berada pada tingkat perguruan tinggi, sedangkan proporsi terbesar pendidikan ibu mahasiswa $(38,3)$ berada pada tingkat SMA/sederajat.

Pekerjaan yang dilakukan orang tua mahasiswa merupakan kegiatan yang menjadi sumber pendapatan orang tua mahasiswa untuk memenuhi kebutuhan hidup keluarganya. Hasil penelitian juga menunjukkan bahwa hampir seluruh ayah mahasiswa memiliki pekerjaan. Ada tiga orang ayah mahasiswa $(2,7 \%)$ yang tidak memiliki pekerjaan karena terkendala oleh masalah kesehatan. Proporsi terbesar ayah bekerja sebagai pegawai negeri sipil $(25,9)$, sedangkan proporsi terbesar ibu mahasiswa bekerja sebagai ibu rumah tangga.
Pendapatan orang tua mahasiswa berkisar antara Rp500.000,00 hingga Rp15.000.000,00. Ada dua keluarga mahasiswa $(1,7 \%)$ yang tidak memiliki pendapatan. Hal ini dikarenakan oleh ayah mahasiswa yang sudah meninggal dan ibu mahasiswa yang tidak bekerja. Rata-rata pendapatan orang tua mahasiswa setiap bulan adalah Rp3.525.432,00 dengan standar deviasi Rp2.451.786,00. Proporsi terbesar pendapatan orang tua mahasiswa $(47,5 \%)$ berada pada rentang kurang dari atau sama dengan Rp2.900.000,00 per bulan dan hanya ada satu keluarga mahasiswa yang memiliki pendapatan pada rentang lebih dari Rp11.600.000,00 per bulan.

Rata-rata jumlah anggota keluarga mahasiswa adalah 5 orang dengan rentang jumlah anggota keluarga sebesar 2-10 orang. Hasil penellitian menunjukkan bahwa persentase terbesar besar keluarga mahasiswa $(48,3 \%)$ berada pada kategori keluarga kecil dengan jumlah keluarga kurang dari atau sama dengan empat orang, sedangkan persentase terkecil besar keluarga mahasiswa $(45,0 \%)$ berada pada keluarga besar dengan jumlah anak lebih dari 5 orang.

Pola asuh makan diukur dalam penelitian ini sebagai faktor eksternal mahasiswa yang juga diduga mempengaruhi gaya hidup dan kebiasaan makan mahasiswa. Pola asuh makan yang diterapkan oleh keluarga mahasiswa dikategorikan dalam tiga kategori, yaitu rendah, sedang, dan tinggi. Hasil penelitian menunjukkan bahwa proporsi terbesar pola asuh makan mahasiswa $(59,2 \%)$ berada pada kategori sedang. Hanya ada 7,5 persen mahasiswa yang berada pada kategori pola asuh makan yang baik. Rata-rata skor mahasiswa pada untuk pola asuh makan adalah sebesar 64,8 persen dengan standar deviasi 11,8 persen.

Kelompok acuan yang paling banyak dipilih oleh mahasiswa adalah teman, keluarga, dan televisi. Teman menjadi kelompok acuan yang paling banyak dipilih dengan proporsi terbesar (84,2\%). Keluarga juga menjadi kelompok acuan selanjutnya yang paling banyak dipilih oleh mahasiswa (10,8\%). Selain itu, lima dari seratus mahasiswa menjadikan televisi sebagai kelompok acuan yang dipilihnya. Televisi yang dimaksud dalam penelitian ini lebih kepada iklan atau selebriti yang dilihat mahasiswa melalui televisi.

\section{Gaya Hidup}

Gaya hidup adalah kegiatan, minat, dan pendapat yang menggambarkan perilaku 
mahasiswa dalam kehidupan sehari-hari. Dalam penelitian ini gaya hidup mahasiswa terbagi menjadi dua kategori, yaitu gaya hidup berorientasi pendidikan dan gaya hidup berorientasi hiburan dan kesehatan. Gaya hidup berorientasi pendidikan yang ditemukan dalam penelitian ini terdiri atas mahasiswa yang aktivitas, minat, dan pendapatnya dalam kehidupan sehari-hari lebih tinggi pada kegiatan belajar. Mereka lebih suka menghabiskan uang dan waktunya untuk membaca buku dan mengerjakan tugas kuliah daripada untuk jalanjalan atau hal-hal lain yang berkaitan dengan hiburan. Mahasiswa dengan gaya hidup berorientasi pendidikan ini juga memiliki perhatian lebih rendah terhadap hal-hal yang berkaitan dengan kegiatan olahraga dan memiliki kebiasaan makan yang kurang baik, seperti tidak makan teratur tiga kali dalam sehari serta menyukai makanan cepat saji dan makanan instan.

Mahasiswa yang termasuk pada kelompok gaya hidup berorientasi hiburan dan kesehatan yang ditemukan dalam penelitian ini adalah seseorang yang lebih suka menghabiskan uang dan waktunya dengan melakukan hal-hal terkait dengan hiburan atau jalan-jalan, suka berolahraga dan memiliki perhatian lebih tinggi dalam hal kesehatan, aktif dalam organisasi, serta lebih suka berakhir pekan bersama teman-teman daripada bersama keluarga. Mahasiswa bergaya hidup berorientasi hiburan dan kesehatan suka menjadi pusat perhatian karena mendapatkan penghargaan diri dari lingkungan sekitar adalah hal yang penting baginya. Selain itu gaya hidup berorientasi hiburan dan kesehatan juga terdiri dari mahasiswa yang menyukai produk dengan merek terkenal karena menurutnya produk yang mahal pasti berkualitas tinggi. Berdasarkan hasil penelitian, diketahui bahwa gaya hidup berorientasi hiburan dan kesehatan merupakan gaya hidup yang lebih banyak dimiliki oleh mahasiswa (64,2\%). Sisanya, sekitar sepertiga mahasiswa $(35,8 \%)$ yang termasuk pada kelompok gaya hidup berorientasi pendidikan.

\section{Pengaruh Faktor Internal dan Faktor Eksternal terhadap Gaya Hidup.}

Hasil uji regresi logistik untuk variabel yang mempengaruhi gaya hidup menghasilkan koefisien determinasi (nagelkerke $R^{2}$ ) sebesar 0,140 . Artinya, 14,0 persen varian gaya hidup sehari dapat dijelaskan oleh variabel yang ada dalam model. Tabel 1 memperlihatkan bahwa variabel usia dan jumlah anggota keluarga berpengaruh posiitif terhadap gaya hidup. Semakin tinggi usia mahasiswa maka peluang mahasiswa untuk memiliki gaya hidup berorientasi pendidikan 1,433 kali lebih tinggi. Mahasiswa yang memiliki jumlah anggota keluarga lebih besar juga berpeluang untuk memiliki gaya hidup berorientasi pendidikan yang lebih tinggi sebanyak 1,329 kali. Sementara itu, semakin banyak mahasiswa memilih televisi menjadi kelompok acuannya maka peluang mahasiswa untuk memiliki gaya hidup berorientasi hiburan dan kesehatan 0,804 kali lebih tinggi.

\section{Pengaruh Faktor Internal, Faktor Eksternal, dan Gaya Hidup terhadap Kebiasaan Makan}

Hasil uji regresi logistik untuk vriabelvariabel yang mempengaruhi kebiasaan makan tiga kali sehari menghasilkan koefisien determinasi (nagelkerke $R$ square) sebesar 0,224 . Artinya, 22,4 persen varian kebiasaan makan tiga kali sehari dapat dijelaskan oleh variabel yang ada dalam model (Tabel 2). Hasil penelitian menunjukkan bahwa variabel yang mempengaruhi kebiasaan makan tiga kali sehari mahasiswa adalah variabel jenis kelamin, usia ayah, kelompok acuan teman, dan kelompok acuan keluarga (Tabel 2).

Tabel 1 Koefisien regresi faktor internal dan faktor eksternal terhadap gaya hidup ${ }^{\text {a) }}$

\begin{tabular}{|c|c|c|c|}
\hline Variabel Bebas & B & Sig. & $\begin{array}{l}\text { Exp } \\
\text { (B) }\end{array}$ \\
\hline Usia (tahun) & 0,360 & $0,082^{*}$ & 1,433 \\
\hline $\begin{array}{l}\text { Jenis kelamin } \\
\text { ( } 1=\text { perempuan, } 0=\text { laki- } \\
\text { laki) }\end{array}$ & 0,350 & 0,405 & 1,419 \\
\hline $\begin{array}{l}\text { Suku bangsa ( } 1=\text { Jawa, } \\
0=\text { lainnya) }\end{array}$ & 0,327 & 0,442 & 1,387 \\
\hline $\begin{array}{l}\text { Jumlah uang saku } \\
\text { (rupiah) }\end{array}$ & 0,000 & 0,433 & 1,000 \\
\hline Usia ibu (tahun) & 0,048 & 0,351 & 1,049 \\
\hline $\begin{array}{l}\text { Pekerjaan ibu ( } 1=\text { bekerja, } \\
0=\text { tidak bekerja) }\end{array}$ & $-0,379$ & 0,366 & 0,684 \\
\hline $\begin{array}{l}\text { Jumlah anggota keluarga } \\
\text { (orang) }\end{array}$ & 0,285 & $0,058^{*}$ & 1,329 \\
\hline Pola asuh makan (skor\%) & $-0,008$ & 0,633 & 0,992 \\
\hline $\begin{array}{l}\text { Kelompok acuan teman } \\
\text { (skor) }\end{array}$ & $-0,118$ & 0,166 & 0,889 \\
\hline Kelompok acuan tv (skor) & $-0,218$ & $0,079^{*}$ & 0,804 \\
\hline Konstanta & $-9,314$ & 0,059 & 0,000 \\
\hline Nagelkerke $R$ Square & & 0,140 & \\
\hline Sig. & & 0,227 & \\
\hline
\end{tabular}

Keterangan:

a) $1=$ gaya hidup berorientasi pendidikan; $0=$ gaya hidup berorientasi hiburan dan kesehatan;

* nyata pada $\mathrm{p}<0,1$ 
Tabel 2 Koefisien regresi faktor internal, faktor eksternal, dan gaya hidup terhadap kebiasaan makan tiga kali sehari

\begin{tabular}{|c|c|c|c|}
\hline Variabel Bebas & B & Sig. & $\begin{array}{l}\operatorname{Exp} \\
(\mathrm{B})\end{array}$ \\
\hline Usia (tahun) & $-0,224$ & 0,317 & 0,799 \\
\hline $\begin{array}{l}\text { Jenis kelamin }(1= \\
\text { perempuan, } 0=\text { laki- } \\
\text { laki) }\end{array}$ & $-0,856$ & $0,050^{*}$ & 0,425 \\
\hline $\begin{array}{l}\text { Jumlah uang saku } \\
\text { (rupiah) }\end{array}$ & 0,000 & 0,682 & 1,000 \\
\hline Usia ayah (tahun) & 0,092 & $0,068^{*}$ & 1,097 \\
\hline $\begin{array}{l}\text { Pekerjaan ibu }(1= \\
\text { bekerja, } 0=\text { tidak } \\
\text { bekerja) }\end{array}$ & $-0,317$ & 0,467 & 0,729 \\
\hline $\begin{array}{l}\text { Pola asuh makan } \\
\text { (skor \%) }\end{array}$ & 0,024 & 0,201 & 1,024 \\
\hline $\begin{array}{l}\text { Kelompok acuan } \\
\text { teman (skor) }\end{array}$ & 0,243 & $0,026^{*}$ & 1,275 \\
\hline $\begin{array}{l}\text { Kelompok acuan } \\
\text { keluarga (skor) }\end{array}$ & 0,290 & $0,010^{*}$ & 1,336 \\
\hline $\begin{array}{l}\text { Gaya hidup }(1= \\
\text { orientasi pendidikan, } \\
0=\text { orientasi hiburan } \\
\text { dan kesehatan) }\end{array}$ & $-0,601$ & 0,170 & 0,548 \\
\hline Konstanta & $-3,167$ & 0,521 & 0,042 \\
\hline Nagelkerke R Square & & 0,224 & \\
\hline Sig. & & 0,015 & \\
\hline
\end{tabular}

Mahasiswa berjenis kelamin perempuan memiliki peluang 0,425 kali lebih rendah untuk memiliki kebiasaan makan tiga kali sehari. Semakin tinggi usia ayah akan membuat mahasiswa berpeluang untuk memiliki kebiasaan makan tiga kali sehari 1,097 lebih tinggi. Sementara itu, semakin banyak mahasiswa memilih teman menjadi kelompok acuannya maka peluang mahasiswa untuk memiliki kebiasaan makan tiga kali sehari akan 1,275 kali lebih tinggi. Selain itu, mahasiswa dengan skor kelompok acuan keluarga yang lebih besar juga berpeluang 1,336 kali lebih tinggi untuk memiliki kebiasaan makan malam (Tabel 2).

Sementara untuk kebiasaan sarapan, hasil uji regresi logistik menunjukkan bahwa model persamaan regresi yang disusun memiliki koefisien determinasi (nagelkerke $R$ square) sebesar 0,141 (Tabel 3). Artinya, 14,1 persen varian kebiasaan sarapan dapat dijelaskan oleh perubahan variabel yang ada dalam model. Sementara itu, sisanya yaitu sebesar 85,9 persen dipengaruhi oleh variabel lain yang tidak diteliti dalam penelitian ini.
Tabel 3 Koefisien regresi faktor internal, faktor eksternal, dan gaya hidup terhadap kebiasaan sarapan

\begin{tabular}{|c|c|c|c|}
\hline Variabel Bebas & $\mathrm{B}$ & Sig. & $\operatorname{Exp}(B)$ \\
\hline Usia (tahun) & $-0,259$ & 0,259 & 0,772 \\
\hline $\begin{array}{l}\text { Jenis kelamin }(1= \\
\text { perempuan, } 0=\text { laki- } \\
\text { laki) }\end{array}$ & $-0,742$ & 0,103 & 0,476 \\
\hline $\begin{array}{l}\text { Jumlah uang saku } \\
\text { (rupiah) }\end{array}$ & 0,000 & 0,443 & 1,000 \\
\hline Usia ayah (tahun) & 0,027 & 0,567 & 1,027 \\
\hline $\begin{array}{l}\text { Pekerjaan ibu ( } 1= \\
\text { bekerja, } 0=\text { tidak } \\
\text { bekerja) }\end{array}$ & 0,569 & 0,217 & 1,766 \\
\hline $\begin{array}{l}\text { Pola asuh makan } \\
\text { (skor \%) }\end{array}$ & 0,020 & 0,288 & 1,020 \\
\hline $\begin{array}{l}\text { Kelompok acuan } \\
\text { teman (skor) }\end{array}$ & 0,172 & $0,099^{*}$ & 1,188 \\
\hline $\begin{array}{l}\text { Kelompok acuan } \\
\text { keluarga (skor) }\end{array}$ & 0,153 & 0,169 & 1,165 \\
\hline $\begin{array}{l}\text { Gaya hidup }(1= \\
\text { orientasi pendidikan, } \\
0=\text { orientasi hiburan } \\
\text { dan kesehatan) }\end{array}$ & $-0,246$ & 0,579 & 0,782 \\
\hline Konstanta & 1,624 & 0,748 & 5,074 \\
\hline Nagelkerke R Square & & 0,141 & \\
\hline Sig. & & 0,219 & \\
\hline
\end{tabular}

Hasil analisis regresi yang disajikan pada Tabel 3 menunjukkan bahwa dari sepuluh variabel bebas yang terdapat pada model, hanya ada satu variabel yang berpengaruh terhadap kebiasaan sarapan mahasiswa, yaitu kelompok acuan teman. Penelitian ini menunjukkan bahwa mahasiswa dengan skor kelompok acuan teman yang lebih besar memiliki peluang 1,188 kali lebih tinggi untuk memiliki kebiasaan melakukan sarapan. Sementara itu, hasil penelitian ini tidak menemukan adanya pengaruh faktor internal, eksternal, dan gaya hidup terhadap kebiasaan makan siang mahasiswa.

Lain halnya dengan kebiasaan makan malam, model regresi yang digunakan untuk menganalisis pengaruh faktor internal, faktor eksternal, dan gaya hidup terhadap kebiasaan makan malam memiliki koefisien determinasi (nagelkerke $R$ square) sebesar 0,393. Artinya, 39,3 persen varian kebiasaan makan malam dapat dijelaskan oleh variabel yang ada dalam model, sedangkan 68,7 persen sisanya dijelaskan oleh variabel lain yang tidak diteliti. Tabel 4 menunjukkan bahwa variabel jenis kelamin dan pekerjaan ibu berpengaruh negatif terhadap kebiasaan makan malam mahasiswa. 
Tabel 4 Koefisien regresi faktor internal, faktor eksternal, dan gaya hidup terhadap kebiasaan makan malam

\begin{tabular}{|c|c|c|c|}
\hline Variabel Bebas & B & Sig. & $\operatorname{Exp}(B)$ \\
\hline Usia (tahun) & 0,299 & 0,466 & 1,348 \\
\hline $\begin{array}{l}\text { Jenis kelamin ( } 1= \\
\text { perempuan, } 0=\text { laki- } \\
\text { laki) }\end{array}$ & $-2,728$ & $0,019^{* \star}$ & 0,065 \\
\hline $\begin{array}{l}\text { Jumlah uang saku } \\
\text { (rupiah) }\end{array}$ & 0,000 & 0,631 & 1,000 \\
\hline Usia ayah (tahun) & 0,122 & 0,204 & 1,130 \\
\hline $\begin{array}{l}\text { Pekerjaan ibu ( } 1= \\
\text { bekerja, } 0=\text { tidak } \\
\text { bekerja) }\end{array}$ & $-2,671$ & $0,003^{* *}$ & 0,069 \\
\hline $\begin{array}{l}\text { Pola asuh makan } \\
\text { (skor \%) }\end{array}$ & 0,040 & 0,170 & 1,041 \\
\hline $\begin{array}{l}\text { Kelompok acuan } \\
\text { teman (skor) }\end{array}$ & $-0,014$ & 0,942 & 0,986 \\
\hline $\begin{array}{l}\text { Kelompok acuan } \\
\text { keluarga (skor) }\end{array}$ & 0,368 & $0,082^{*}$ & 1,445 \\
\hline $\begin{array}{l}\text { Gaya hidup ( } 1= \\
\text { orientasi } \\
\text { pendidikan, } 0= \\
\text { orientasi hiburan } \\
\text { dan kesehatan) }\end{array}$ & $-0,514$ & 0,521 & 0,598 \\
\hline Konstanta & $-9,545$ & 0,271 & 0,000 \\
\hline $\begin{array}{l}\text { Nagelkerke } R \\
\text { Square }\end{array}$ & & 0,393 & \\
\hline Sig. & & 0,004 & \\
\hline
\end{tabular}

Hasil penelitian menunjukkan bahwa mahasiswa berjenis kelamin laki-laki berpeluang 0,065 kali lebih tinggi untuk memiliki kebiasaan makan malam dibandingkan dengan mahasiswa yang berjenis kelamin perempuan. Sementara itu, mahasiswa dengan ibu yang bekerja memiliki peluang 0,069 lebih rendah untuk terbiasa melakukan makan malam. Akan tetapi, Mahasiswa yang memilih keluarga sebagai kelompok acuannya berpeluang untuk memiliki kebiasaan makan malam 1,445 kali lebih tinggi (Tabel 4).

Model regresi yang digunakan untuk menganalisis pengaruh faktor internal, faktor eksternal, dan gaya hidup terhadap kebiasaan makan camilan memiliki koefisien determinasi (nagelkerke $R$ square) sebesar 0,198 (Tabel 5). Artinya, 19,8 persen varian kebiasaan makan camilan dapat dijelaskan oleh variabel yang ada dalam model. Mahasiswa perempuan berpeluang 3,006 kali lebih tinggi untuk memiliki kebiasaan makan camilan dibandingkan dengan mahasiswa laki-laki. Selain itu, semakin tinggi skor keluarga yang dipilih mahasiswa sebagai kelompok acuan maka peluang mahasiswa untuk memiliki kebiasaan makan camilan pun akan 1,279 kali lebih tinggi.
Tabel 5 Koefisien regresi faktor internal, faktor eksternal, dan gaya hidup terhadap kebiasaan makan camilan

\begin{tabular}{|c|c|c|c|}
\hline Variabel Bebas & $\mathrm{B}$ & Sig. & $\operatorname{Exp}(B)$ \\
\hline Usia (tahun) & $-0,250$ & 0,294 & 0,779 \\
\hline $\begin{array}{l}\text { Jenis kelamin }(1= \\
\text { perempuan, } 0=\text { laki- } \\
\text { laki) }\end{array}$ & 1,101 & $0,014^{* *}$ & 3,006 \\
\hline $\begin{array}{l}\text { Jumlah uang saku } \\
\text { (rupiah) }\end{array}$ & 0,000 & 0,765 & 1,000 \\
\hline Usia ayah (tahun) & 0,069 & 0,152 & 1,072 \\
\hline $\begin{array}{l}\text { Pekerjaan ibu ( } 1= \\
\text { bekerja, } 0=\text { tidak } \\
\text { bekerja) }\end{array}$ & 0,673 & 0,151 & 1,961 \\
\hline $\begin{array}{l}\text { Pola asuh makan } \\
\text { (skor \%) }\end{array}$ & $-0,013$ & 0,487 & 0,987 \\
\hline $\begin{array}{l}\text { Kelompok acuan } \\
\text { teman (skor) }\end{array}$ & 0,114 & 0,303 & 1,121 \\
\hline $\begin{array}{l}\text { Kelompok acuan } \\
\text { keluarga (skor) }\end{array}$ & 0,246 & $0,044^{* *}$ & 1,279 \\
\hline $\begin{array}{l}\text { Gaya hidup (1= } \\
\text { orientasi } \\
\text { pendidikan, } 0= \\
\text { orientasi hiburan } \\
\text { dan kesehatan) }\end{array}$ & 0,092 & 0,840 & 1,096 \\
\hline Konstanta & 0,802 & 0,873 & 2,229 \\
\hline $\begin{array}{l}\text { Nagelkerke } R \\
\text { Square }\end{array}$ & & 0,198 & \\
\hline Sig. & & 0,048 & \\
\hline
\end{tabular}

Keterangan : ${ }^{* *}$ nyata pada $p<0,05$

\section{PEMBAHASAN}

Gaya hidup menggambarkan seluruh pola seseorang dalam beraksi dan berinteraksi di dunia (Kotler \& Amstrong, 2008). Dalam penelitian ini ditemukan bahwa gaya hidup mahasiswa terbagi menjadi dua kategori, yaitu gaya hidup berorientasi pendidikan dan gaya hidup berorientasi hiburan dan kesehatan. Gaya hidup berorientasi pendidikan terdiri atas mahasiswa yang aktivitas, minat, dan pendapatnya dalam kehidupan sehari-hari lebih tinggi pada kegiatan belajar.

Berdasarkan hasil penelitian, diketahui bahwa gaya hidup berorientasi hiburan dan kesehatan merupakan gaya hidup yang lebih banyak dimiliki oleh mahasiswa $(64,2 \%)$. Sementara itu, hanya sekitar sepertiga mahasiswa yang termasuk pada kelompok gaya hidup berorientasi pendidikan. Hasil tersebut menunjukkan bahwa proporsi mahasiswa yang memiliki memiliki perhatian lebih tinggi pada kegiatan yang berkaitan dengan kuliah lebih rendah, padahal mahasiswa yang menjadi responden dalam penelitian ini merupakan mahasiswa yang masih aktif. Hal ini menunjukkan fenomena bahwa meskipun status sebagai mahasiswa 
tidak membuat gaya hidup mereka mengarah ke hal-hal yang terkait dengan kuliah saja. Pengaruh globalisasi dan berkembangnya teknologi adalah dua kemungkinan yang dapat menyebabkan pergeseran gaya hidup mahasiswa ini.

Penelitian ini menunjukkan bahwa semakin tinggi usia mahasiswa dan semakin besar jumlah anggota keluarga maka semakin besar pula peluang mahasiswa untuk memiliki gaya hidup berorientasi pendidikan. Akan tetapi, semakin rendah usia mahasiswa dan semakin kecil jumlah anggota keluarga, maka mahasiswa akan berpeluang lebih besar untuk memiliki gaya hidup berorientasi hiburan dan kesehatan. Hal ini sesuai dengan penelitian Suwanvijit dan Promsa-ad (2009) yang menemukan bahwa faktor-faktor yang mempengaruhi gaya hidup konsumen di Thailand adalah usia, jenis kelamin, status pernikahan, dan pendapatan. Selain itu, mahasiswa yang lebih banyak memilih televisi menjadi kelompok acuannya akan semakin berpeluang untuk memiliki gaya hidup berorientasi hiburan dan kesehatan.

Mahasiswa yang berjenis kelamin laki-laki memiliki peluang lebih tinggi untuk memiliki kebiasaan makan tiga kali sehari. Hal ini dimungkinkan terjadi karena laki-laki dewasa memiliki kebutuhan energi yang lebih tinggi dibandingkan dengan perempuan dewasa. Menurut Widyakarya Nasional Pangan dan Gizi tahun 2004, pria dewasa yang berusia 19 sampai 29 tahun membutuhkan asupan energi sebesar $2550 \mathrm{kkal}$ dan protein sebesar 60 gram per hari sedangkan wanita usia dewasa membutuhkan asupan energi sebesar 1900 kkal dan protein sebesar 50 gram per hari. Selain itu, mahasiwa dengan usia ayah lebih tinggi akan memiliki peluang lebih besar untuk memiliki kebiasaan makan tiga kali sehari. Hasil penelitian juga menunjukkan bahwa semakin tinggi skor kelompok acuan teman maka peluang mahasiswa untuk memiliki kebiasaan makan tiga kali sehari pun akan semakin besar. Temuan ini menegaskan bahwa teman sebaya berpengaruh besar terhadap kebiasaan makan (Arisman, 2004).

Kelompok acuan teman juga mempengaruhi kebiasaan mahasiswa dalam melakukan sarapan. Kebiasaan sarapan mahasiswa kemungkinan dapat dipengaruhi oleh ketersediaan waktu di pagi hari sebelum memulai aktivitas karena menurut hasil penelitian ini, sebagian besar mahasiswa yang tidak terbiasa melakukan sarapan memiliki alasan karena tidak memiki cukup waktu sehingga tidak sempat untuk melakukan sarapan.

Mahasiswa berjenis kelamin perempuan memiliki peluang lebih rendah untuk melakukan kebiasaan makan malam, tetapi memiliki peluang yang lebih tinggi untuk melakukan kebiasaan makan camilan. Hal ini mendukung hasil penelitian Przystawski et al. (2011) bahwa remaja putri sangat menyukai makanan camilan dan mengonsumsinya setiap hari disamping mengonsumsi makanan utama. Ibu yang tidak bekerja juga membuat peluang mahasiswa lebih besar untuk melakukan kebiasaan makan malam daripada mahasiswa dengan ibu yang bekerja. Hal ini dimungkinkan terjadi karena ibu yang tidak bekerja memiliki lebih banyak waktu di rumah sehingga dapat lebih memerhatikan dan menyiapkan makanan untuk keluarganya.

Sementara itu, mahasiswa yang menjadikan keluarga sebagai kelompok acuannya memiliki peluang yang lebih besar untuk memiliki kebiasaan makan tiga kali sehari, makan malam, dan makan camilan. Suhardjo (1989) menyatakan bahwa keluarga merupakan faktor utama dalam pembentukan pola perilaku makan dan juga dalam pembinaan kesehatan keluarga. Hal ini juga membuktikan bahwa keluarga tetap menjadi penjaga pintu (gatekeeper) yaitu seseorang yang memiliki peranan dalam mengendalikan kebiasaan makan mahasiswa sesuai dengan teori saluran menurut Lewin yang tertera dalam Khumaidi (1988).

Penelitian ini juga tidak menemukan satu pun variabel bebas yang mempengaruhi kebiasaan makan siang. Hal ini kemungkinan dapat terjadi karena makan siang dianggap sebagai kebutuhan yang harus selalu dipenuhi oleh mahasiswa setiap harinya dalam kondisi apapun. Karena di siang hari mahasiswa membutuhkan asupan energi untuk menggantikan energi yang telah dikeluarkannya di pagi hari dan untuk melanjutkan aktivitasnya lagi.

\section{SIMPULAN DAN SARAN}

Berdasarkan hasil penelitian, proporsi terbesar mahasiswa berada pada gaya hidup berorientasi hiburan dan kesehatan, yang menunjukkan bahwa mahasiswa dalam penelitian ini lebih memfokuskan aktivitas, minat, dan opini dalam kehidupan sehariharinya pada hal-hal yang berhubungan dengan hiburan, olahraga, kesehatan, dan organisasi dibandingkan dengan hal-hal yang berhubungan dengan kegiatan perkuliahan. 
Berdasarkan hasil uji regresi logistik, diketahui bahwa variabel usia dan jumlah anggota keluarga berpengaruh positif terhadap gaya hidup. Usia mahasiswa yang lebih tinggi dan jumlah anggota keluarga yang lebih besar membuat peluang mahasiswa untuk memiliki gaya hidup berorientasi pendidikan pun akan lebih besar. Sementara itu, peluang untuk memiliki gaya hidup berorientasi hiburan dan kesehatan lebih besar ditemukan pada mahasiswa yang lebih banyak memilih televisi sebagai kelompok acuannya.

Hasil uji regresi logistik juga menunjukkan bahwa kebiasaan makan tiga kali sehari dipengaruhi oleh jenis kelamin, usia ayah, dan kelompok acuan (teman dan keluarga). Kebiasaan sarapan mahasiswa dipengaruhi oleh kelompok acuan teman. Sementara itu, kebiasaan makan malam mahasiswa dipengaruhi oleh jenis kelamin, pekerjaan ibu, dan kelompok acuan keluarga. Jenis kelamin dan kelompok acuan keluarga berpengaruh signifikan pada kebiasaan makan camilan.

Penelitian selanjutnya diharapkan dapat mengukur gaya hidup dan kebiasaan makan pada periode perkembangan yang lain atau melihat pengaruh faktor-faktor lain yang mungkin dapat mempengaruhi gaya hidup serta kebiasaan makan yang belum diukur dalam penelitian ini. Penelitian ini juga menghasilkan dua kategori gaya hidup yang merupakan potret mahasiswa saat ini sehingga menarik untuk dikaji dalam lima atau sepuluh tahun mendatang apakah terjadi pergeseran pada gaya hidup mahasiswa.

\section{DAFTAR PUSTAKA}

Arisman. (2004). Gizi dalam Daur Kehidupan. Jakarta: Penerbit buku kedokteran EGC.

Engel, J. F., Blackwell, R. D., \& Miniard, P. W. (1994). Perilaku Konsumen Jilid 1. Jakarta: Binarupa Aksara.

Hurlock, E. (1980). Psikologi Perkembangan: Suatu Pendekatan Sepanjang Rentang Kehidupan. Jakarta: Erlangga.

Jelinic, J. D., Nola, I. A., \& Matanic, D. (2008). Living or Away from Home-Impact on Student's Eating Habits. Materia Socio Medica, 20 (4), 204-208.

Khumaidi, M. (1988). Gizi Masyarakat. Jakarta: Departemen Pendidikan dan Kebudayaan.

Kotler, P. (1985). Manajemen Pemasaran, Marketing Management, Analisis,
Perencanaan, dan Pengendalian. Edisi keempat. Jakarta: Erlangga.

\& Amstrong, G. (2008). Prinsipprinsip Pemasaran: Edisi 12. Jilid 1. Jakarta: Erlangga.

Mowen, J. C., \& Minor, M. (1998). Consumer Behavior, $4^{\text {th }}$ Edition. New Jersey: Prantice Hall.

Mustopa, N. (2003). Studi tentang Gaya Hidup, Pola Konsumsi Pangan, dan Status Gizi Mahasiswa Universitas Pakuan [skripsi]. Fakultas Pertanian, Institut Pertanian Bogor.

Papalia, D. E., Olds, S. W., \& Feldman, R. D. (2008). Human Development: Tenth Edition. New York: McGraw-Hill Companies, Inc.

Phujiyanti, Y. (2004). Identifikasi Gaya Hidup dan Kebiasaan Makan Mahasiswa IPB [skripsi]. Bogor: Fakultas Pertanian, Institut Pertanian Bogor.

Przystawski, J., Stelmach, M., Grygiel-Gorniac, B., Mardas, M., \& Walkowiak, J. (2011). Dietary Habits and Nutritional Status of Female Adolescents from the Great Poland Region. Polish Journal of Food and Nutrition Science, 61 (1), 73-78.

Shiffman, L. G., \& Kanuk, L. L. (2004). Consumer Behavior: Eight Edition. New Jersey: Pearson Prantice Hall.

Sop, M. M. K., Gouado, I., Tetanye, E., \& Zollo, P. H. A. (2010). Nutritional Status, Food Habits, and Energi Profile of Young Adult Cameroonian University Students. African Journal of Food Science, 4 (12), 748-753.

Suhardjo. (1989). Sosio Budaya Gizi. Bogor: Departemen Pendidikan dan Kebudayaan, Direktorat Jendral Pendidikan Tinggi, Pusat Antar Universitas Pangan dan Gizi, IPB.

Sundari, A. (2003). Studi tentang Gaya Hidup, Pola Konsumsi Pangan, dan Status Gizi Siswa SMU Negeri 3 Bogor [skripsi]. Bogor: Fakultas Pertanian, Institut Pertanian Bogor.

Suwanvijit, W., \& Promsa-ad, S. (2009).The Insight Study of Consumer Life-style and Purchasing Behaviors in Songkla Province, Thailand. International Journal of Marketing Studies, 1 (2), 66-73.

Turner, J. S., \& Helms, D. B. (1986). Contemporary Adulthood: Third Edition. Kanada: CBS College Publishing. 
